\title{
Research database of burnt areas over Russia based on high resolution remote sensing data
}

\author{
Alexandr V. Kashnitskii ${ }^{1}$, Ivan V. Balashov ${ }^{1}$, Ilya A. Saigin ${ }^{1}$, Fedor V. Stytsenko ${ }^{1}$ and \\ Evgeniy A. Loupian ${ }^{1}$ \\ ${ }^{1}$ Space Research Institute (IKI RAS), Moscow, Russia
}

\begin{abstract}
The paper presents the sample database of vegetation cover damaged by wildfires, obtained from high spatial resolution remote sensing data (up to 10 meters per pixel). At the time of publication, more than 6 thousand fires with a total area of more than 12 million ha were mapped and confirmed with the focus on forest fires. The database covers the period from 2009 to 2020 and is constantly being updated. The presented database may be of interest for various scientific wildfire researches and can be used as training basis for a fully automatic high-resolution fire mapping method development.
\end{abstract}

\section{Keywords}

Burned area, post-fire damage, vegetation damage, database, wildfire, natural fires, Landsat, Sentinel-2, remote sensing, forest fire monitoring.

\section{Introduction}

Wildfires on the territory of Russia annually cover huge areas and lead to many negative consequences. One of the main ways to assess the scale and dynamics of wildfires is to analyze information about the area covered by fire, places of occurrence and contours of wildfires. Such information based on remote sensing data is currently obtained based on the following approaches:

- active fire detection (based on remote sensing data with a spatial resolution from hundreds of meters to kilometer), for example [1];

- fire caused surface reflectance change mapping. Here we can distinguish separately the work performed on the basis of moderate resolution data (hundreds of meters per pixel), for example [2], and on the basis of high-resolution data (up to $10 \mathrm{~m}$ per pixel), for example [3].

The method based on active fire data is based on fairly stable and fully automatic methods for detecting active fire pixels with further generation of active fires conjunct polygons. The disadvantages of this method are primarily associated with the relatively low spatial resolution data used (from hundreds of meters to kilometers).

Based on the moderate spatial resolution satellite data $(100-500 \mathrm{~m})$, it was possible to create fully automatic methods of fire-caused damaged vegetation mapping for the entire territory

SDM-2021: All-Russian conference, August 24-27, 2021, Novosibirsk, Russia

$\bigoplus$ kashnizky@gmail.com (A.V. Kashnitskii)

(c) (i) $\odot 2021$ Copyright for this paper by its authors. Use permitted under Creative Commons License Attribution 4.0 International (CC BY 4.0).

CEUR Workshop Proceedings (CEUR-WS.org) 
of Russia [2]. These methods make it possible to obtain long-term homogeneous data series of forest cover damaged areas. Despite of reliable applicability of these methods for nationand regional-scale fire researches, they can be not enough accurate and not applicable for a number of cases, namely for relatively small forest fires analysis [4, 5]. Approaches based on high resolution data processing (up to $10 \mathrm{~m}$ per pixel) gives the most accurate results for individual fires. However, at present there are no fully automatic methods for processing such data, which would allow obtaining information rather reliably over large areas. Therefore, for mass processing of information at the level of large regions or the country as a whole, it is necessary to use approaches that require the participation of operators. This lead, on the one hand, to rather large costs and time of data processing, and on the other hand, it introduces a certain subjectivity in the processing process. All this makes it difficult to obtain homogeneous long-term data series across the entire territory of Russia. Therefore, at present, uniform series of such information throughout the whole Russia territory for a long time period does not exist.

This paper presents a research database of wildfires mapped based on high resolution remote sensing data. This database was created at the Space Research Institute of the Russian Academy of Sciences (IKI RAS), mainly based on data from the Landsat and Sentinel-2 satellite systems, using as reference active fire data from MODIS (AQUA, TERRA satellites) and VIIRS (NPP satellite). The database covers the period from 2009 to 2020 and is constantly being updated. The presented database, although it does not cover all natural fires on the territory of Russia for the specified period, may be of interest for various scientific studies. The work describes the data used to fill the database, the methodology for filling it, as well as its main characteristics.

\section{The data used and the method of filling the database}

\subsection{Used data}

To determine the places of wildfires occurrence, the information of active fire from MODIS (satellites AQUA, TERRA) and VIIRS (satellite NPP) data was used. A special method was previously developed in IKI RAS that allows to combine individual observations of hot spots pixels, generate burnt area polygons and to retrace their temporal evolution [6]. In this work, we used ready-made polygons of wildfires, which were obtained as described in [6] by combining individual hot spots on the images (including images taken at different times). Thus, based on the information of active fire at the inlet, in each case there was a complete natural fire contour. This contour obtained from active fire data was used to search and further obtain a contour of a wildfire based on the analysis of fire-caused reflectance change of vegetation cover using data of a higher spatial resolution. For this, data from OLI (Landsat-8 satellite), ETM+ (Landsat-7 satellite), TM (Landsat-4, Landsat-5 satellites), MSI (Sentinel 2A, Sentinel 2B satellites) were used. In addition to this information, in some difficult cases, the performer used data from the KMSS (Meteor-M series satellites) and MSS (Kanopus-V, BKA satellites) for clarification. In all cases, data of processing level not lower than L1C (radiometrically and geometrically corrected, geographically referenced data) were used. The data of channels in the ranges Green, Red, NIR, SWIR were used. Basically, we used data without atmospheric correction, since the used scheme for detecting vegetation damage does not require this operation to be performed. However, in some cases (if available in the archive), data with atmospheric correction were used. More 
details on the features of the data used are given below. All data used were provided by the IKI-Monitoring Shared Use Center [7].

\subsection{Method of filling the database}

The described database was created at the Space Research Institute of the Russian Academy of Sciences (IKI RAS) with the participation of a large number of specialists. Each specialist performed the same standardized set of actions to create one polygon of post-fire damaged vegetation. The high level of automation and standardization of actions to create the individual fire polygon made it possible to attract as performers not only employees of the institute, but also third-party specialists, including students of the Faculty of Space Research of Lomonosov Moscow State University worked within the framework of pre-graduation practice. All created polygons were independently checked by a trusted expert among IKI RAS employees. Thus, errors that could arise were excluded, including cases caused by lack of experience of performers.

All actions for the selection and processing of data were carried out on the basis of the resources provided by the Center for Shared Use of IKI-Monitoring [7]. At all stages, the performers used only the cartographic interface of the information systems VEGA-Science (http://sci-vega.ru) and Vega-Les (http://forest.geosmis.ru). For the task, no other processing resources and data sources were used, except for those available through the web interface of these systems.

The scheme of filling the database of post-fire damaged vegetation is shown in Figure 1. The main steps of individual burnt area polygon creation were as follows.

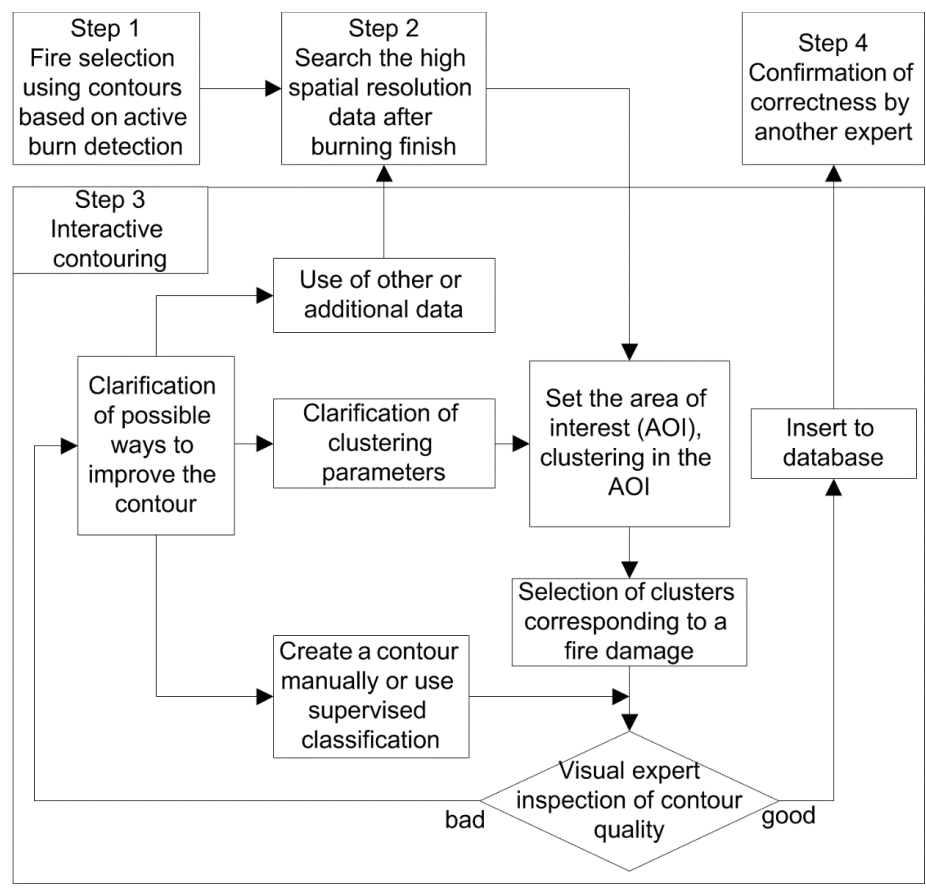

Figure 1: Scheme of filling the database of post-fire damage to vegetation. 
Step 1. Selection of a wildfire detected and mapped based on active fire information.

Step 2. Selecting high spatial resolution data image.

Step 3. Interactive contouring based on vegetation damage analysis using high resolution data.

Step 4. Checking the correctness of the contour creation by an independent expert.

Step 1, Step 2 and Step 4 of the scheme were considered in more detail in [8]. Step 3 of the scheme was described in more detail in [9]. Below, we briefly describe the main features of each step.

\subsubsection{Step 1 and Step 2. Choice of fire and data}

The first step in the replenishment scheme is the selection of an observed active fire. As mentioned above, the fire contour according to active fire data was obtained as a result of combining hot spots [6]. After that, in the second step, the expert selected high-resolution cloud-free satellite data, which were obtained after the end of fire. The end of the fire was assessed by the absence of detected hot spot pixels and the absence of smoke plumes on high resolution image. The data were selected as close as possible to the end of fire and no later than three weeks after. In some difficult cases, retreat from these principles were allowed by performer decision. For example, several images could be used for different dates after the fire end. Data before the start of the fire could also be used to analyze the pre-fire state of vegetation. To perform clustering at step 3, we selected channels in the Red, NIR and SWIR ranges of the electromagnetic spectrum. Data in the Green channel was also used for visual assessment.

\subsubsection{Step 3. Interactive contouring based on vegetation damage analysis based on high spatial resolution data}

As already noted, the information systems VEGA-Science (http://sci-vega.ru) and Vega-Les (http: //forest.geosmis.ru) were used to create the polygons of post-fire damage to the vegetation cover. In these systems, based on the resources of the "IKI-Monitoring" Shared Use Center [7], the work with various Earth remote sensing (ERS) data from large distributed archives is implemented. In addition to access to data, these systems provide remote users with ample opportunities for searching, analyzing and processing remote sensing information. Such opportunities are provided to users in the form of specialized information tools based on the solutions described in article [10]. Such tools allow using only a web browser to carry out rather complex data processing from large distributed archives. Step 3 of the described scheme for replenishing the database is implemented using one of such tools that allow for a trainable and non-trainable classification of the raster data available in the system. With its help, the following interactive algorithm is implemented.

1. A "rough" interactive delineation of the burnt areas is carried out. The purpose of this operation is to determine the spatial area of interest (AOI), in which further clustering will be performed.

2. Unsupervised clustering of the selected data is carried out by the $k$-means method in the given AOI.

3. Clusters corresponding to damaged areas are selected in expert mode, then all selected clusters are combined and vectorized. 
4. An expert visual assessment of the quality of the contour is carried out. If the quality is satisfactory, the contour is entered into the database. In case of unsatisfactory quality, the expert decides on ways to improve the quality. There are three main options:

4.1) refine clustering parameters, for example, more precisely set AOI, choose a different initial number of clusters, use filtering results, etc.;

4.2) return to the selection of data, for example, for other dates;

4.3) Define the contour in full manual mode.

Also, in the absence of cloud-free data on the fire area, the expert could completely refuse to create its contour using high spatial resolution data. For example, there were many such cases in the years before the launch of the Landsat-8 satellite.

\subsubsection{Step 4. Checking the correctness of the contour creation by an independent expert}

The high level of automation and standardization of the interactive contouring scheme has made it possible to reduce the subjectivity of decision-making at every step. Note that the applied scheme does not require high qualifications from a performer. All steps are performed quickly enough and are reduced to a set of actions that are easy to understood. All this made it possible to involve a wide range of specialists in solving the problem. However, to eliminate errors, an independent control of the contours entered in the database was used. A highly qualified independent expert checked each created polygon. Such an expert in a specially created interface visually checked each contour combined with the remote sensing data. As a result, the expert assigned a verification status to each circuit. The database presented as a result contains only confirmed contours.

\section{Main characteristics of the database}

\subsection{Description of the database and its coverage}

The database includes burnt area polygons (based on high spatial resolution data), characteristics of satellite data used (including the date), as well as additional information derived from active fire data.

In total, at the time of publication, 6853 verified contours of post-fire damaged vegetation with a total area of more than 12.5 million ha are available in the database. The temporal coverage of the data is limited to $2009-2020$, but the database is constantly being updated. Table 1 shows the distribution of polygon number and area by year of fire.

\subsection{Database access}

Access to the analysis of the resulting contour layer from the database is available in the cartographic interface of the information systems VEGA-Science (http://sci-vega.ru) and VegaLes (http://forest.geosmis.ru). The data is located in the "Annual Products" tab. Access for scientific organizations and for scientific research to data and the possibilities of their processing in the VEGA-Science system is open and free. Also, upon request to the authors of the article, it 


\section{Table 1}

Database coverage at time of publication. Distribution by years of the number of contours of post-fire damage to vegetation and their areas.

\begin{tabular}{ccc}
\hline Year & Count of contours by year & Total area by year, Ha \\
\hline 2009 & 5 & 1197 \\
2010 & 266 & 136848 \\
2011 & 1702 & 1621951 \\
2012 & 1071 & 2102782 \\
2013 & 1944 & 4243355 \\
2015 & 526 & 1363697 \\
2016 & 137 & 603359 \\
2017 & 150 & 464091 \\
2018 & 301 & 743636 \\
2019 & 389 & 1108831 \\
2020 & 362 & 358544 \\
\hline Total & 6853 & 12748291 \\
\hline
\end{tabular}

is possible to form a layer for a convenient quick view of all the contours for a specific year. For example, at the link http://forest.geosmis.ru/mapviewer/?id=1624462112996 the layer for the year 2019 is available, at the link http://forest.geosmis.ru/mapviewer/?id=1624523110391 the layer for the year 2020 is available. A cloud-free Landsat composite image for the corresponding year was used as a substrate. Other data access mechanisms are available upon request.

\section{Conclusion}

Information on forest burnt areas based on high resolution data can be used for solving a number of scientific and applied problems. The database presented in the work is quite unique, taking into account the methods of its obtaining and coverage. Despite the fact that the database does not cover all wildfires in Russia for the period from 2009 to 2020 , it is constantly being updated. Combining this database with information obtained from active fire data will improve the quality and capabilities of wildfire monitoring and analyzing.

In the future, it is planned to use the database as a basis for creating a fully automatic high resolution burnt area mapping method. Using this method, the authors propose to assess damaged vegetation area (primarily forest) caused by all wildfires on the territory of Russia (if data are available) rather quickly and automatically.

It should be noted that the scheme of applying new burnt areas polygons to the database is quite standardized and does not require high qualifications from performer. All operations for the selection and analysis of data are carried out using a browser via cartographic web interface. Thus, the performer does not need to download and upload a large volumes of remote sensing data and there is no need for complex and expensive software or large computing power on the PC being used. In this regard, the authors see opportunities for interaction with various scientific groups involved in the analysis of wildfires. Within the framework of such interaction, it is possible for various scientific groups to use the resources of the IKI-Monitoring Shared Use Center for burnt area mapping using ready proven technology. 


\section{Acknowledgments}

This work was supported by the grant MK-4903.2021.1.5. The acquisition and processing of satellite data was carried out using the capabilities of the IKI-Monitoring Shared Use Center [6].

\section{References}

[1] Loupian E.A., Balashov I.V., Bartalev S.A., Bourtsev M.A., Dmitriev V.V., Senko K.S., Krasheninnikova Yu.S. Forest fires in Russia: Specifics of the 2019 fire season // Sovremennye Problemy Distantsionnogo Zondirovaniya Zemli iz Kosmosa. 2019. Vol. 16. No. 5. P. 356-363. DOI:10.21046/2070-7401-2019-16-5-356-363.

[2] Bartalev S.A., Stytsenko F.V., Egorov V.A., Loupian E.A. Sputnikovaya otsenka gibeli lesov Rossii ot pozharov (Russia's forest fire damage estimation) // Lesovedenie. 2015. No. 2. P. 83-94.

[3] Bartalev S.A., Loupian E.A., Stytsenko F.V., Panova O.Yu., Efremov V.Yu. Ekspresskartografirovanie povrezhdenii lesov Rossii pozharami po sputnikovym dannym Landsat (Rapid mapping of forest burnt areas over Russia using Landsat data) // Sovremennye Problemy Distantsionnogo Zondirovaniya Zemli iz Kosmosa. 2014. Vol. 11. No. 1. P. 9-20.

[4] Stytsenko F.V., Bartalev S.A., Ivanova A.A., Loupian E.A., Sychugov I.G. Vozmozhnosti otsenki ploshchadei lesnykh pozharov v regionakh Rossii na osnove dannykh sputnikovogo detektirovaniya aktivnogo goreniya (Forest burnt area assessment possibilities in regions of Russia based on active fires detection by satellites) // Sovremennye Problemy Distantsionnogo Zondirovaniya Zemli iz Kosmosa. 2016. Vol. 13. No. 6. P. 189-298. DOI:10.21046/2070-7401-2016-13-6-289-298.

[5] Ponomarev E.I., Shvetsov .G. Satellite detection of forest fires and geoinformation methods for calibrating of the result // Issledovaniye Zemli iz Kosmosa. 2015. No. 1. P. 84-84.

[6] Lupyan E.A., Bartalev S.A., Balashov I.V., Egorov V.A., Ershov D.V., Kobets D.A., Sen'ko K.S., Stytsenko F.V., Sychugov I.G. Sputnikovyi monitoring lesnykh pozharov v 21 veke na territorii Rossiiskoi Federatsii (tsifry i fakty po dannym detektirovaniya aktivnogo goreniya) (Satellite monitoring of forest fires in the $21^{\text {st }}$ century in the territory of the Russian Federation (facts and figures based on active fires detection)) // Sovremennye Problemy Distantsionnogo Zondirovaniya Zemli iz Kosmosa. 2017. Vol. 14. No. 6. P. 158-175. DOI:10.21046/2070-7401-2017-14-6-158-175.

[7] Loupyan E.A., Proshin A.A., Burtsev M.A., Kashnitskiiy A.V., Balashov I.V., Bartalev S.A., Konstantinova A.M., Kobets D.A., Mazurov A.A., Marchenkov V.V., Matveev A.M., Radchenko M.V., Sychugov I.G., Tolpin V.A., Uvarov I.A. Opyt ekspluatatsii i razvitiya tsentra kollektivnogo pol'zovaniya sistemami arkhivatsii, obrabotki i analiza sputnikovykh dannykh (TsKP "IKI-Monitoring") (Experience of development and operation of the "IKIMonitoring" center for collective use of systems for archiving, processing and analyzing satellite data) // Sovremennye Problemy Distantsionnogo Zondirovaniya Zemli iz Kosmosa. 2019. Vol. 16. No. 3. P. 151-170. DOI:10.21046/2070-7401-2019-16-3-151-170.

[8] Bartalev S.A., Egorov V.A., Efremov V.Yu., Loupian E.A., Stytsenko F.V., Flitman E.V. Otsenka ploshchadi pozharov na osnove kompleksirovaniya sputnikovykh dannykh razlichnogo 
prostranstvennogo razresheniya MODIS i Landsat-TM/ETM+ (Integrated burnt area assessment based on combine use of multi-resolution MODIS and Landsat-TM/ETM+ satellite data) // Sovremennye Problemy Distantsionnogo Zondirovaniya Zemli iz Kosmosa. 2012. Vol. 9. No. 2. P. 9-27.

[9] Kashnitskii A.V., Loupian E.A., Bartalev S.A., Bartalev S.S., Balashov I.V., Efremov V.Yu., Stytsenko F.V. Optimizatsiya interaktivnykh protsedur kartografirovaniya garei v informatsionnykh sistemakh distantsionnogo monitoringa prirodnykh pozharov (Optimization of burn mapping interactive procedures in remote fire monitoring information systems) // Sovremennye Problemy Distantsionnogo Zondirovaniya Zemli iz Kosmosa. 2015. Vol. 12. No. 4. P. 7-16.

[10] Kashnitskii A.V., Lupyan E.A., Balashov I.V., Konstantinova A.M. Technology for designing tools for the process and analysis of data from very large scale distributed satellite archives // Atmospheric and Oceanic Optics. 2017. Vol. 30. No. 1. P. 84-88. 